\title{
KUTATÁS KÖZBEN
}

Educatio 30 (4), pp. 682-693 (2021)

DOI: $10.1556 / 2063.30 .2021 .4 .9$

\section{ZÖLD KÉSZSÉGEK \\ A FELSŐOKTATÁSBAN}

\author{
BARNA ORSOLYA* - SZALMÁNÉ CSETE MÁRIA \\ Budapesti Müszaki és Gazdaságtudományi Egyetem, \\ Környezetgazdaságtan és Fenntartható Fejlődés Tanszék
}

Beérkezett: 2021. június 9., elfogadva: 2021. november 29.

A klímaváltozás komplex problémaköre egyre jelentősebb társadalmi, gazdasági és környezeti kihívást jelent napjainkban. A zöld gazdaság koncepciója olyan összetett megoldási lehetőséget jelenthet, amely mindezen problémák megoldására irányuló erőfeszítéseket képes integrálni. A zöld gazdaságra való átállás megvalósításában kiemelt szerepet tölthet be az oktatás, hiszen a különféle átképzések és a zöld készségek fejlesztése is egyre inkább előtérbe kerül. Jelen tanulmány magyar és lengyel környezetmérnök alapszakok oktatói és hallgatói körében végzett kérdőíves felmérés segítségével vizsgálja a zöld készségek szerepét. A kutatás eredményei alapján látható, hogy a zöld készség fogalma lassan kezd elterjedni az egyetemi ökoszisztémákban.

Kulcsszavak: zöld gazdaság, zöld készségek, felsőoktatás, környezetmérnök alapképzés

The complex issue of climate change poses a significant social, economic and environmental challenge today. The concept of a green economy could offer a complex solution that can integrate all efforts to solve these problems. Education can play a key role in the transition to a green economy, as various retraining and the development of green skills are becoming more and more important. The present study examines green skills at Hungarian and Polish environmental engineering Bachelor programs. The results of the research show that the concept of green skill is slowly beginning to spread in the university ecosystems.

Keywords $\ddagger$ green economy, green skills, higher education, environmental engineering $\mathrm{BSc}$

\footnotetext{
* Levelező szerző: Barna Orsolya, Budapesti Műszaki és Gazdaságtudományi Egyetem, Környezetgazdaságtan és Fenntartható Fejlődés Tanszék, 1117 Budapest, Magyar tudósok krt. 2. E-mail: barna.orsolya@gtk.bme.hu
} 


\section{Bevezetés}

$\mathrm{A}$

klímaváltozás olyan komplex kihívásokkal terhelt összetett és szerteágazó problémakör, amelyhez kapcsolódóan a hagyományos megoldások nem bizonyultak, illetve bizonyulnak kellóképpen hatékonynak; így nagy szükség van az interdiszciplináris szemléletmód elötérbe kerülésére, s olyan személyes készségek fejlesztésére, mint például az új, megváltozott körülményekhez történő folyamatos alkalmazkodási képesség, a kreatív problémamegoldó képesség vagy a rendszerszintü gondolkodás. Az oktatás, mint az egyik legfontosabb szocializációs tényező, kulcsfontosságú eszköz lehet társadalmunk fenntarthatóság felé történő elmozdításában (Szalmáné-Buzási-Barna 2020), és elősegítheti a hallgatók zöld gazdasággal és társadalommal összhangban álló viselkedésének és attitüdjeinek kialakítását.

A zöld gazdaságot a különböző szervezetek, kutatók igen eltérően határozzák meg (Bailey-Caprotti 2014; ILO 2011; Nurdiansya-Mulyanti-Sucita 2019; UN 2011, UN 2021; WRI 2011), ugyanakkor két témakör mindegyik meghatározásban megjelenik és fontos részét képezi, nevezetesen a természet és a környezet védelme, valamint az emberi jól(l)ét javítása és a társadalmi fejlődés ösztönzése. A zöld gazdaság alapvetően a zöld technológiák és innovációk elóállítóira támaszkodik. Az egyetemek, a kutatóintézetek, a társadalom és a kormányok közötti szimbiotikus jellegűnek tekinthető kapcsolat rendkívül fontos szerepet játszhat a zöld gazdaság támogatásában. A felsőoktatási intézmények jelentős gazdasági szereplők, már csak abból adódóan is, hogy nagyszámú embert foglalkoztatnak, oktatnak és gyakran segítik a hallgatókat az első munkahely, gyakornoki pozíció megszerzésében és partnerségben állhatnak a helyi önkormányzatokkal, forprofit és nonprofit szervezetekkel, valamint különféle méretü és profilú vállalkozásokkal. Így a felsőoktatási intézmények a zöld munkaerő képzői, és a klímaváltozással kapcsolatos tudásteremtés során (technológiai innováció, magatartásváltozás, kormányzási kísérletek stb.) a felsőoktatási intézmények zöld munkahelyeket is teremthetnek (Lee-Van Der Heijden 2019).

Jelen tanulmány a lengyel és magyar környezetmérnöki alapszakok oktatói és hallgatói körében végzett online kérdőíves felmérés segítségével vizsgálja a zöld készségek szerepét. A kutatás alapvető célja az volt, hogy megvizsgálja, megjelenik-e a zöld készségek fejlesztése a környezetmérnöki alapképzéseken, és amennyiben megjelenik, akkor milyen formában és mértékben. A két ország felsőoktatási intézményeinek a zöld készségek fejlesztésére irányuló összehasonlító elemzése az egész közép-európai térségben segítheti egy olyan hatékony oktatási rendszer létrehozásának megvalósítását, amely elősegíti a zöld gazdaságra való átállást.

\section{Zöld készségek}

A zöld gazdaságra való áttérés pozitív hatásai maximalizálhatók az erőforrás-hatékony folyamatok és technológiák által megkövetelt kompetenciák egyidejü fejlesztésével. A zöld készségek szinte minden szakma, munka- és feladatkör, valamint foglalkozás részévé válnak előbb-utóbb, hasonlóképpen integrálódva, mint korábban az informatikai készségek (CEDEFOP 2012). A zöld készségek fejlesztése az Európai Bizottság programjában is szerepel, melyben egy olyan európai kompetenciakeretet állítottak ösz- 
sze, amely irányt mutat az éghajlatváltozással és a fenntartható fejlődéssel kapcsolatos ismeretek, készségek és attitüdök fejlesztéséhez (European Commission 2020).

Ahogy a zöld gazdaság, a zöld munka, úgy a zöld készségek fogalmára vonatkozóan sem található egységes, nemzetközileg elfogadott definíció. Általánosságban a zöld készségeket olyan, a fenntarthatósághoz szükséges képességeknek tekintik, amelyek a munkavállalók azon technikai készségeit, ismereteit, értékrendjét és hozzáállását jelentik, amelyek elősegítik a fenntartható társadalmi, gazdasági és környezeti eredmények elérését az üzleti életben, az iparban és a közösségben (Sern-Zaime-Foong 2017). Vagyis olyan tudásként, képességekként, értékekként és attitüdként határozhatók meg, amelyekre szükség van egy olyan társadalomban, amely hozzájárul az emberi tevékenység környezetre gyakorolt hatásának csökkentéséhez (CEDEFOP 2012).

A zöld készségeket a szakirodalom a Bloom-féle taxonómia alapján (Bloom et al. 1956) általában három nagy csoportra osztja:

1. kognitív terület: ismeretek (például a környezetvédelemmel kapcsolatos ismeretek);

2. pszichomotoros terület: készségek/képességek (például az energiafogyasztás minimalizálására vagy az üvegházhatású gázok csökkentésére való készségek);

3. affektív terület: attitüdök/értékek (például az egyén motivációja a természeti erőforrások megőrzésére) (Sern-Zaime-Foong 2017).

Pavlova (2012) tanulmányában 3 fö zöld készség kategóriát különböztet meg, mégpedig az általános zöld készségeket, kiegészíthető vagy fejleszthető zöld készségeket és a

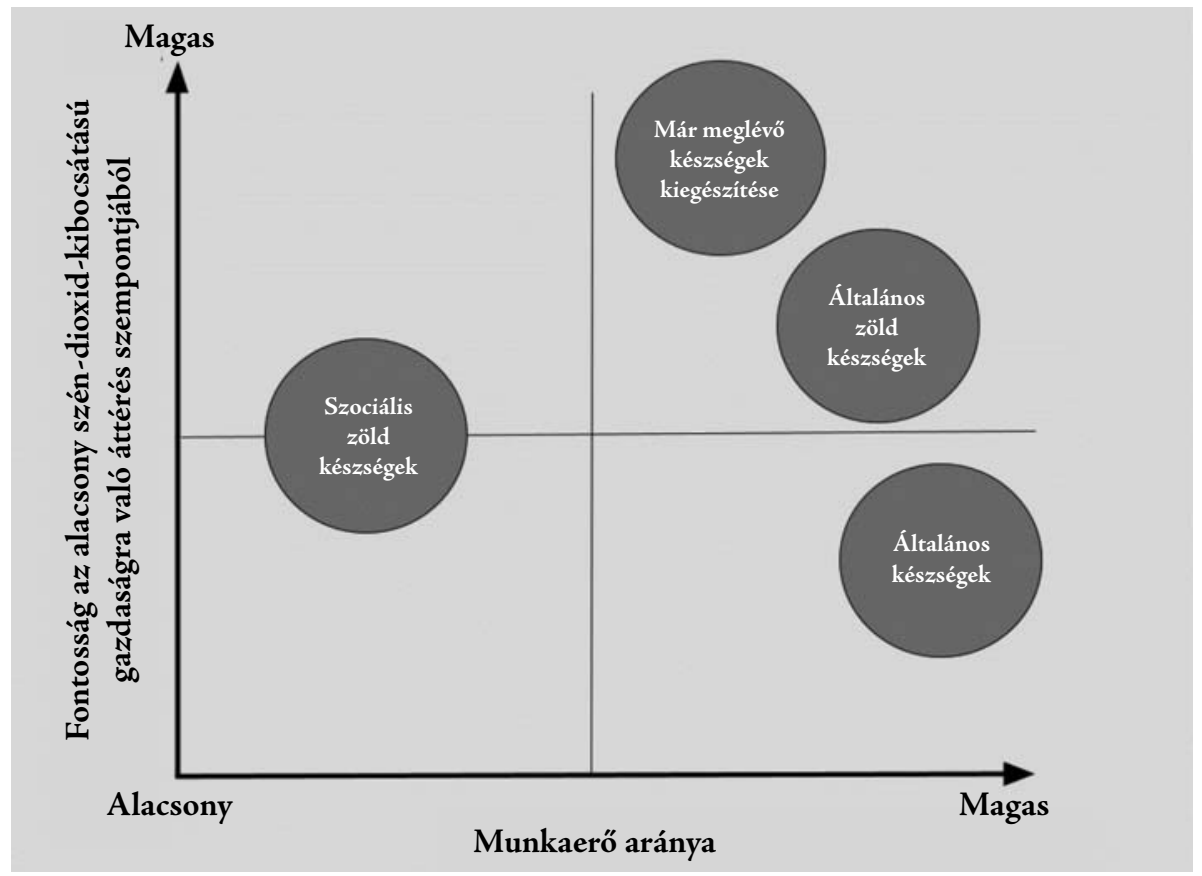

1. ábra: Zöld készségek fontossága az alacsony szén-dioxid-kibocsátású gazdaságra való áttérés szempontjából. Forrás: Saját szerkesztés Pavlova (2012) alapján 
specifikus zöld készségeket. Ezeket az alacsony kibocsátású gazdaság felé történő átalakulás szempontjából helyezte fontossági sorrendbe vizsgálatai során (1. ábra). A képességfejlesztéssel kapcsolatban első helyen szerepel a készségek kiegészítése vagy fejlesztése („top-up”), ami a már meglévő képességek fejlesztésével segíti, hogy egy munkavállaló egy zöld foglalkozásban helyezkedhessen el. Szinte minden szakma, munka- és feladatkör, illetve foglalkozás esetében mérvadóvá válnak az általános zöld készségek (környezettudatosság, koordinációs és irányítási készség, vállalkozói készség, innovációs képesség, STEM készségek, analitikus gondolkodás képessége), amelyek segíthetik a zöld gazdaság kérdéseinek, kihívásainak az általános megértését. Fontosak lesznek a speciális zöld készségek is, amelyek kifejezetten új zöld munkakörök kapcsán alakulnak ki, melyek országonként változóak lehetnek (például a megújuló energia iparághoz, a hulladékgazdálkodáshoz, vagy a zöld üzletvezetéshez kapcsolódó új feladatok elvégzéséhez szükséges készségek) (Pavlova 2012).

A kívánt változások elérése felé való elmozdulás elősegítése érdekében a munkaadók és a képzési szolgáltatók együttműködése is nélkülözhetetlen fontosságú (CEDEFOP 2011). Ha zöld készségeket kívánnak az egyetemek biztosítani, akkor felül kell vizsgálni a meglévő alaptanterveket és képzési programokat, valamint át kell képezni az oktatókat is.

\section{A kutatás módszertana és mintája}

A kvantitatív kutatáshoz egy zárt kérdésekből álló alapkérdőív összeállítására került sor, amit annak megfelelően módosítottunk, hogy oktatók vagy hallgatók voltak annak fókuszában. A 2021 januárjában zajlott online kérdőíves felmérésben összességében hét hazai és tizenkét lengyelországi felsőoktatási intézmény környezetmérnöki alapképzésben érintett oktatói és hallgatói vettek részt. Összesen 257-en töltötték ki a kérdőívet, aminek megoszlását az 1. táblázat mutatja. A felmérés nem tekinthető reprezentatívnak, mert a válaszok között egyik országból sem szerepel hiánytalanul a mérnökképzést adó egyetemek listája.

1. táblázat: A felmérésben részt vevők megoszlása (fö)

\begin{tabular}{lcc}
\hline & Egyetemi oktatók & Hallgatók \\
\hline Magyarország & 31 & 109 \\
Lengyelország & 38 & 79 \\
\hline Forrás: Saját adatfelvétel & &
\end{tabular}

A magyarországi egyetemek közül 7 egyetemről kerültek ki a kérdőívet kitöltő hallgatók és oktatók. A hallgatói kérdőívet az Óbudai Egyetemről, míg az oktatói kérdőívet a Soproni Egyetemröl töltötték ki a legtöbben (2. ábra).

Lengyelországból 12 egyetemről érkeztek az oktatói kitöltések, legnagyobb számban a Wrocławi Környezet- és Élettudományi Egyetemről (Uniwersytet Przyrodniczy we Wrocławiu). Hallgatók részéről nagyobb számú kitöltés érkezett, de kevesebb, összesen 5 egyetemről. A legnagyobb számban szintén a Wrocławi Környezet- és Élettudományi Egyetem hallgatói töltötték ki a kérdőívet (3. ábra). 


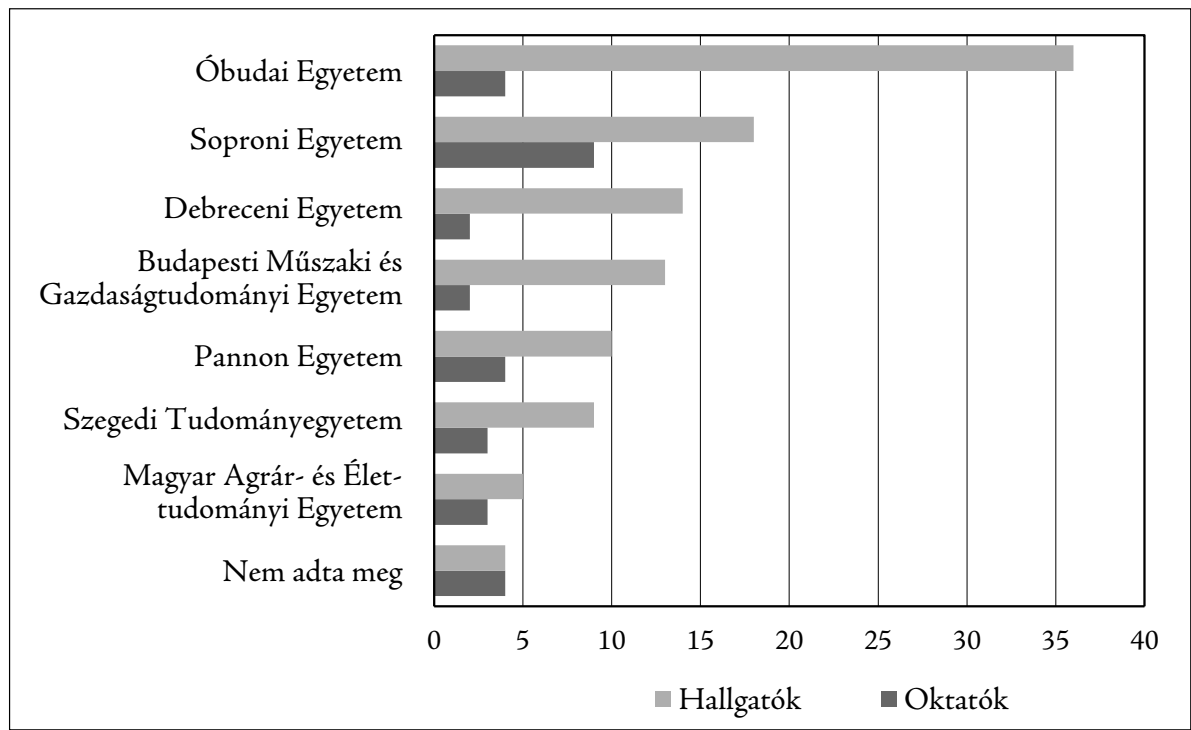

2. ábra: A kérdőivet kitöltő magyar hallgatók és oktatók száma felsőoktatási intézmények szerint (fö). Forrás: Saját adatfelvétel

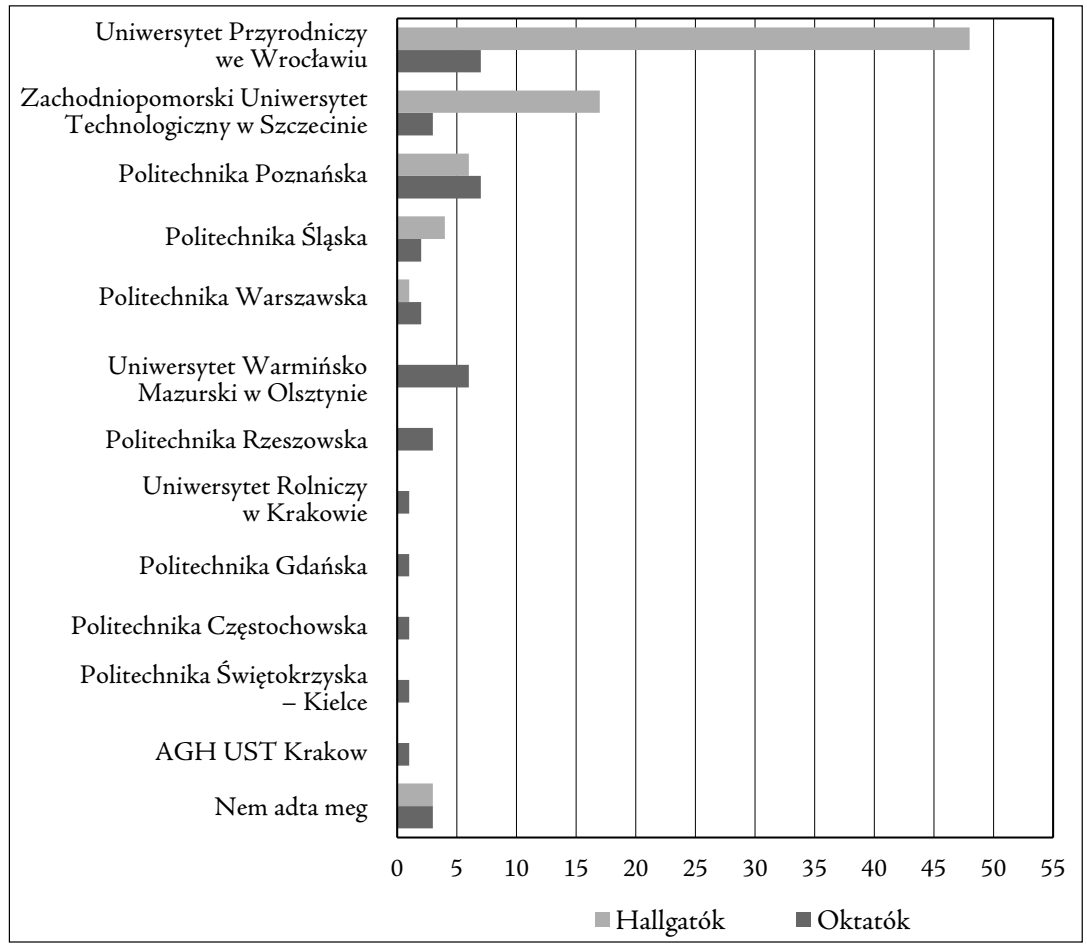

3. ábra: A kérdőívet kitöltő lengyel hallgatók és oktatók száma felsőoktatási intézmények szerint (fö). Forrás: Saját adatfelvétel 


\section{A kutatás eredményei}

Kérdőíves felmérésünkben kíváncsiak voltunk arra, hogy a hallgatók és oktatók miként vélekednek a zöld gazdaság és a zöld készségek közötti lehetséges kapcsolatról. Ennek érdekében arra kértük a válaszadókat, hogy jelöljék meg, egyetértenek-e azzal a kijelentéssel, hogy a zöld gazdaság elérése érdekében szükség van a zöld készségek fejlesztésére, mely utóbbi technikai, szakmai specifikus készségeket és általános, puha készségeket is magába foglal. Az összes válaszadó hallgató és oktató 86,4\%-a értett egyet ezzel a kijelentéssel, míg mindössze 3,1\%-uk nem. Mindkét nemzet esetében az oktatók nagyobb arányban értettek egyet az állítással: mind a magyar, mind a lengyel oktatók esetében 90\% fölötti az egyetértők aránya, míg a magyar és a lengyel hallgatók körében egyaránt $84 \%$. A válaszok között egyéb kategóriát is megadtunk, melyet akkor jelölhettek a válaszadók, ha tudáshiányra (a zöld készségek fogalom ismeretének hiányára) hivatkozva nem tudták elfogadni az állítást (4. ábra).

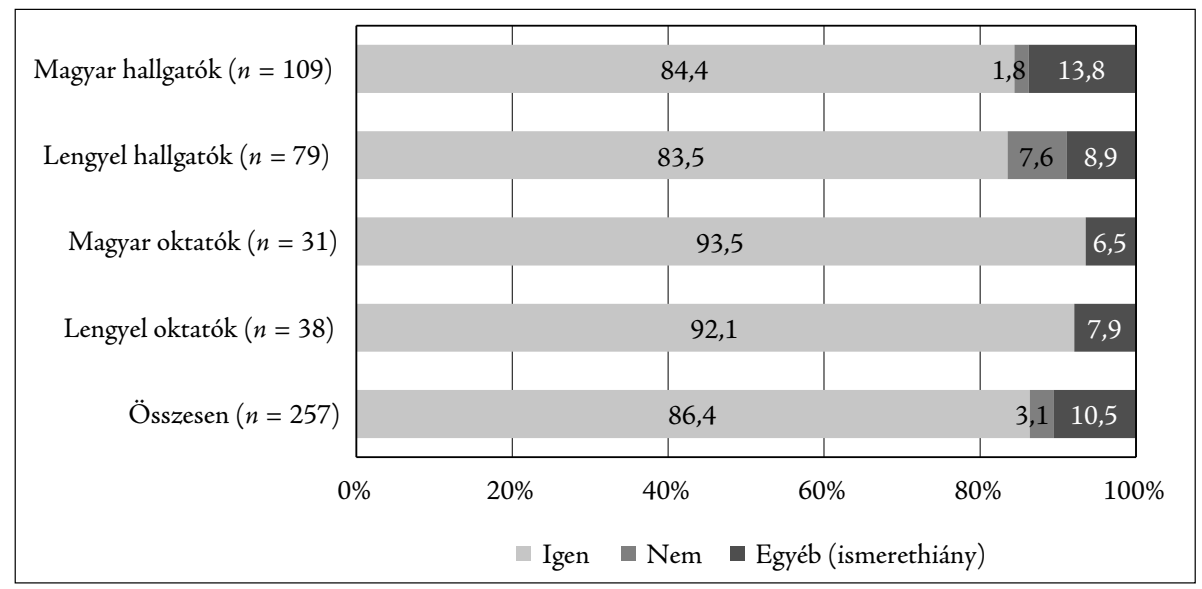

4. ábra: A zöld gazdaság és a zöld készségek közötti kapcsolat megítélése a magyar és a lengyel hallgatók és oktatók szerint (\%). Megjegyzés: A feltett kérdés: Egyetért-e a következő állítással: „A zöld gazdaság elérése érdekében szükség van a zöld készségek fejlesztésére. A zöld készségek mind technikai, mind szakmai specifikus készségeket, és általános, puha készségeket is magukba foglalnak."

Forrás: Saját adatfelvétel

Kutatásunk egyik lényeges célja volt a zöld készségekkel kapcsolatos ismeretek feltárása. A kérdőívbe ezért egy olyan listát tettünk, amelyből a válaszadók kiválaszthatták azokat, melyek szerintük a zöld készségek közé tartoznak. A válaszadók túlnyomó többsége választotta a környezettudatosságot (minden csoportban 90\%-hoz közeli eredménnyel), a szaktudást (energiahatékonyság, hulladékgazdálkodás, vízgazdálkodás, fenntartható fejlődés stb. témakörökben) (80\% fölötti eredménnyel) és a szakmai gyakorlatot (energiahatékonyság, hulladékgazdálkodás, vízgazdálkodás, fenntartható fejlődés stb. témakörökben) (60-70\% közötti eredménnyel). A magyar hallgatók három készségnél kimagasló arányban jelezték a zöld készségekhez tartozást, ezek az innovációs készség, rugalmasság és az alkalmazkodási készség. A lengyel oktatók esetében több tényező (innovációs készség, alkalmazkodási készség, kreativi- 


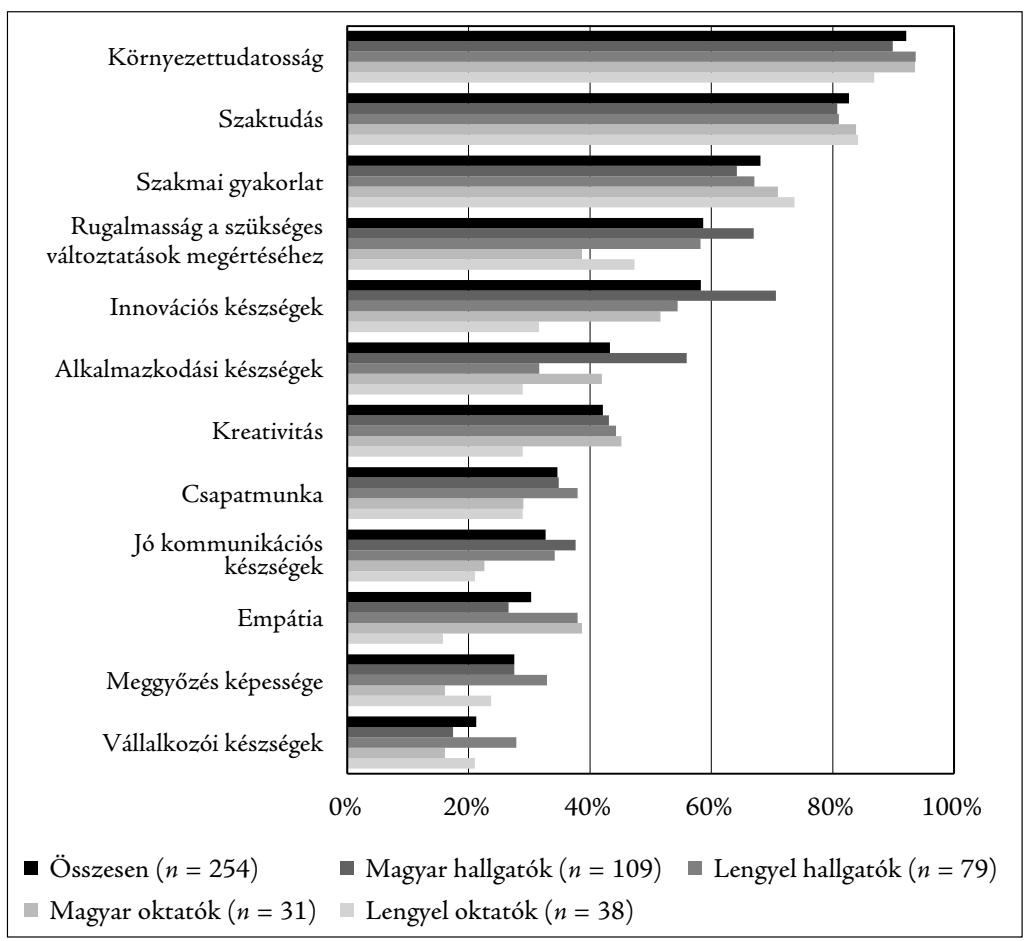

5. ábra: Zöld készségek a magyar és a lengyel hallgatók és oktatók szerint (\%). Megjegyzés: A feltett kérdés: Véleménye szerint az alábbiak közül melyek tartoznak a zöld készségek közée (Több választ is jelölhetett.) Forrás: Saját adatfelvétel

tás, csapatmunka, jó kommunikációs készség, empátia) kapcsán is az figyelhető meg, hogy kisebb arányban jelölték meg, mint a többi vizsgált csoport. Általánosságban elmondható, hogy valamennyi vizsgált csoportban a legkevesebb jelölést a vállalkozói készség, a meggyőzés képessége, az empátia, a jó kommunikációs készség és a csapatmunka kapta (5. ábra).

A hallgatók esetében arra is választ kerestünk, hogy mit gondolnak, tanultak-e zöld készségeket az alapképzésük folyamán. A magyar hallgatók majdnem kétszer nagyobb arányban mondták (63,3\% szemben a lengyel 38\%-kal), hogy igen, tanultak zöld készségeket. A lengyel hallgatók csaknem négytizede (39,2\%) nem tudta eldönteni, mely arány a magyar hallgatók körében $30 \%$ alatti. A magyar hallgatókhoz $(5,5 \%)$ képest kimagaslóan sok lengyel hallgató $(22,8 \%)$ jelentette ki kategorikusan, hogy nem tanultak zöld készségeket (6. ábra).

Ezzel párhuzamosan az oktatóktól azt kérdeztük, hogy tanítanak-e zöld készségeket a kurzusaikon. A magyar oktatók csaknem háromnegyede $(74,2 \%)$ tanít saját bevallása szerint zöld készségeket. Ezzel szemben a lengyel kollegáiknak csak kicsivel több mint fele (52,6\%) mondta azt, hogy tanít zöld készségeket (7. ábra).

A következő kérdésben arra kerestük a választ, hogy miként lehetne az oktatókat arra ösztönözni, hogy jobban integrálják a zöld készségek fejlesztését a kurzusaikba. Az oktatók legnagyobb arányának (55\% magyar és 58\% lengyel) több időre lenne szüksége ehhez. A második és harmadik legnagyobb arányban jelölt válasz a több segédanyag 


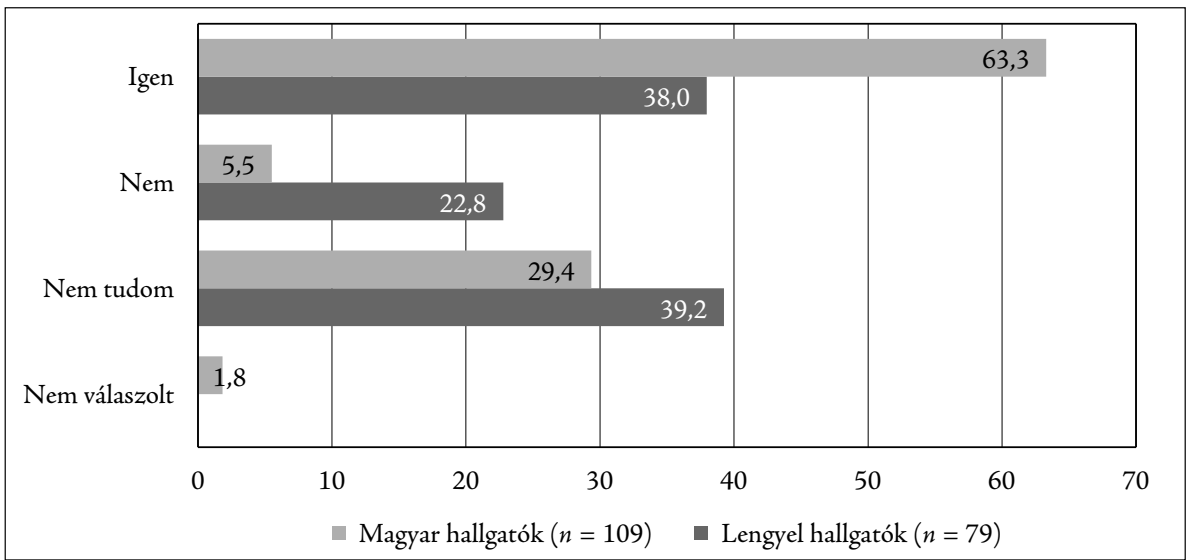

6. ábra: Zöld készségek elsajátítása a környezetmérnök alapképzésen a magyar és a lengyel hallgatók szerint (\%). Megjegyzés: A feltett kérdés: A környezetmérnök alapképzése folyamán Ön elsajátított zöld készségeket? Forrás: Saját adatfelvétel

(53\% a magyar és 45\% a lengyel oktatók körében) és az ilyen irányú továbbképzés (39\% a magyar és $29 \%$ a lengyel oktatók körében) volt. Ennél lényegesen kevesebben jelölték a feljebbvalók, kollégák támogatását (39\% a magyar és 29\% a lengyel oktatók körében) (8. ábra).

A soron következő kérdés azokat az akadályokat próbálta feltárni, amelyek a zöld készségek oktatását hátráltatják. A magyar oktatók kiemelkedően magas arányban (53\% szemben a lengyel oktatók 26\%-ával) jelezték, hogy nincs ilyen akadály. Az ezt követő három leggyakoribb akadálynak a segédanyagok hiányát, az egyéb adminisztratív jellegű teendők, illetve a leadandó elméleti anyag nagysága miatti időhiányt, valamint a zöld készségek tantárgyon belüli irrelevanciáját jelölték meg. A lengyel oktatók jelentősen magasabb aránya számolt be valamilyen akadályról, és csaknem mindegyik fel-

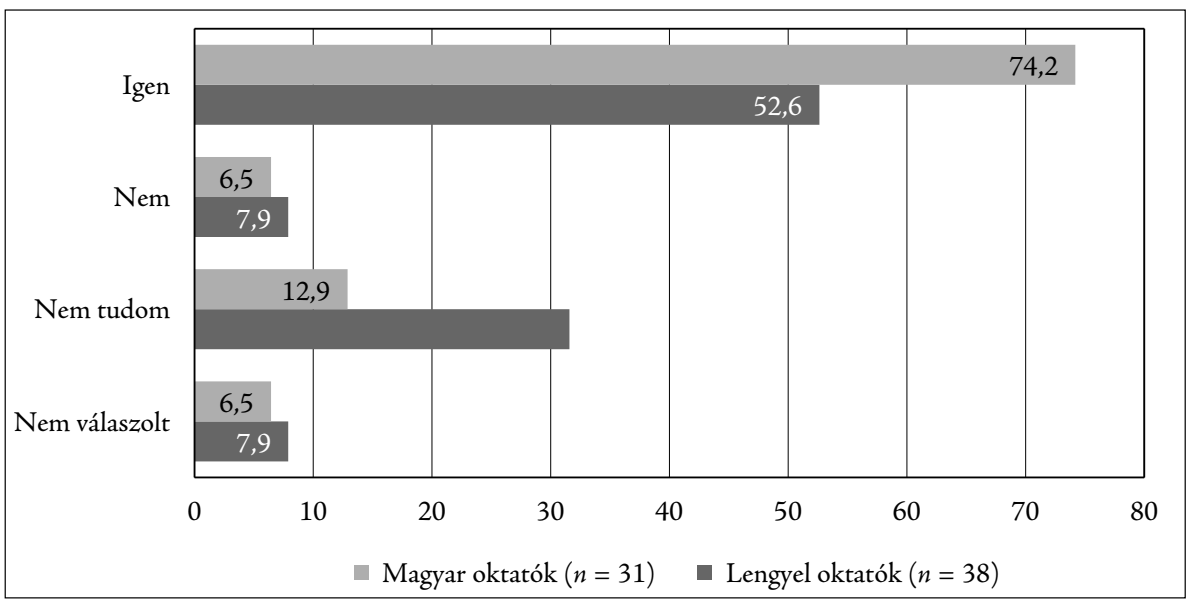

7. ábra: Zöld készségek oktatása a környezetmérnök alapképzésen a magyar és a lengyel oktatók szerint (\%). Megjegyzés: A feltett kérdés: Ön tanít zöld készségeket? Forrás: Saját adatfelvétel 


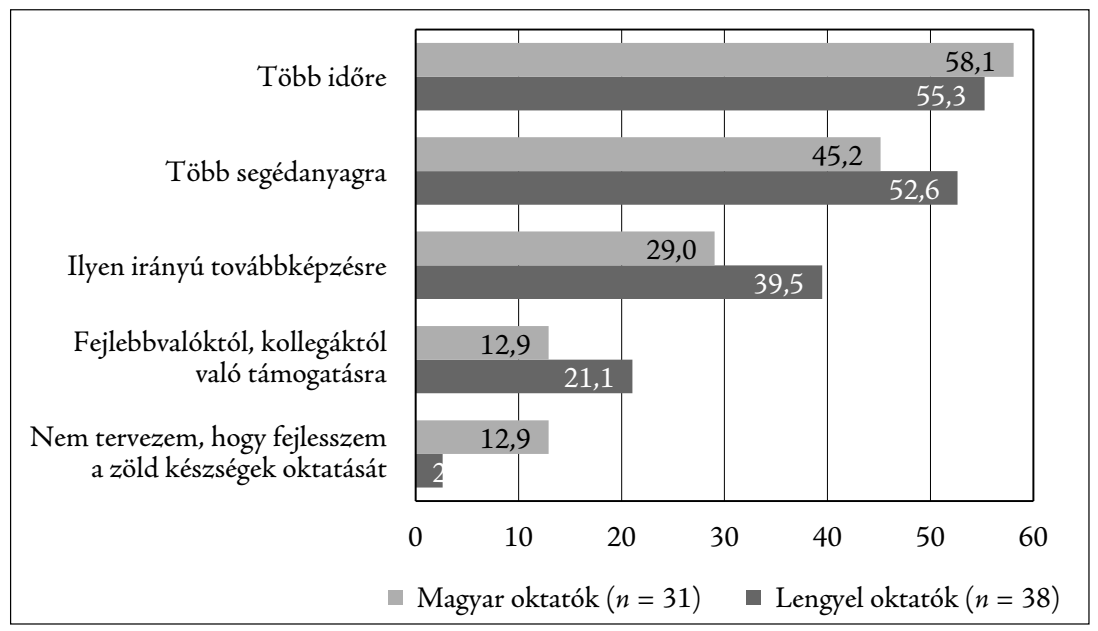

8. ábra: A zöld készségek oktatását ösztönző tényezők a magyar és a lengyel oktatók szerint (\%). Megjegyzés: A feltett kérdés: Mire lenne szüksége, hogy fejlessze a zöld készségek oktatását az Ön tantárgyaiban? (Több választ is jelölhetett.) Forrás: Saját adatfelvétel

sorolt akadályt gyakoribbnak tartják, mint magyar kollégáik. Különösen az időhiány, a segédanyagok hiánya, valamint a pandémia miatti online oktatás nehézségei okoztak gondok a számukra (9. ábra).

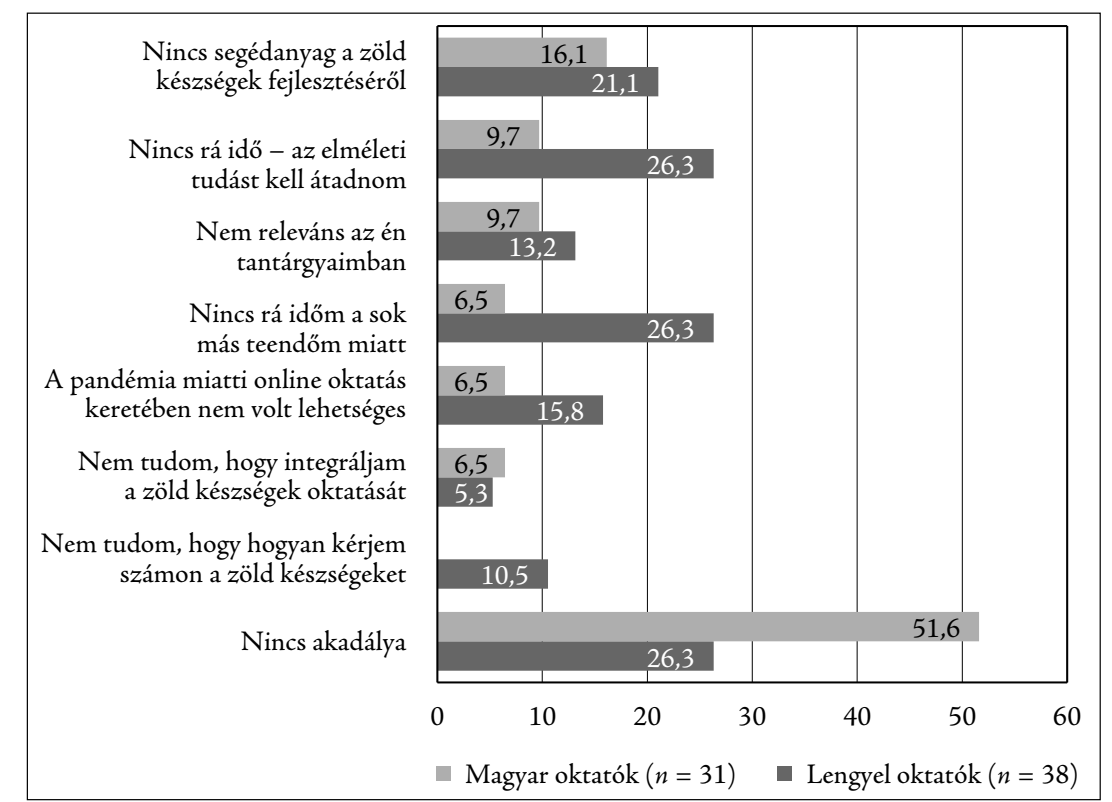

9. ábra: A zöld készségek oktatását akadályozó tényezők a magyar és a lengyel oktatók szerint (\%). Megjegyzés: A feltett kérdés: Milyen akadálya van, hogy a zöld készségeket tanítsa? (Több választ is jelölhetett.) Forrás: Saját adatfelvétel 


\section{Összegzés}

Jelen tanulmány egy online kérdőíves felmérés keretében arra kereste a választ, hogy az elöírt készségfejlesztés során megjelenik-e a zöld készségek fejlesztése a környezetmérnöki alapképzéseken a magyar, illetve a lengyel felsőoktatási intézményekben. A zöld készségek megjelenési formáira, a fő akadályozó tényezők vizsgálatára is kitértünk felmérésünkben, oktatói és hallgatói szempontból is körüljárva a vizsgált témakört. A felmérés unikális mind a két országban, hiszen az eddigi kutatások többsége a környezeti nevelés hatásaira fókuszált a hallgatók körében (például Zsóka-MarjainéSzéchy 2011), illetve a hallgatók környezeti tudatosságát mérte (például Cynk 2017).

A kutatás eredményei alapján látható, hogy a zöld készség fogalma lassan kezd elterjedni az egyetemi ökoszisztémákban. A válaszok alapján is tükröződni látszik, hogy a vizsgált alapképzés esetében mind az oktatók, mind a hallgatók nyitottak zöld készségfejlesztésre tanulmányaik alatt, mely a környezetmérnök alapszak környezeti témakör iránti érintettségével is magyarázható. Szintén ennek lehet köszönhető, hogy a vizsgált hallgatók és az oktatók a zöld készségek közé a környezettudatosságot, valamint a szakmai tudást és gyakorlatot sorolták. A kevésbé egyértelmü, puha készségeket kisebb arányban sorolták a zöld készségek közé a megkérdezettek, mely különösen a vállalkozói készség és a meggyőzés képessége kapcsán volt szembetűnő. Ezzel szemben az innovációs készséget - főleg a magyar hallgatók - magas arányban sorolták a zöld készségek közé. Mind a magyar, mind a lengyel oktatók az időhiányt és a segédanyagok hiányát jelölték meg a zöld készségek oktatását leginkább akadályozó tényezőként. Ezenfelül nagy arányuk az ilyen irányú továbbképzések szükségességét is üdvözítőnek tartaná. Ezzel kapcsolatban megjegyezzük, hogy a zöld készségekre vonatkozó segédanyagok és továbbképzések kifejlesztése és elterjesztése szakmai és szakpolitikai akarat függvénye.

Azok az oktatási intézmények, amelyek zöld készségeket és fenntartható fejlődési elemeket alkalmaznak az alapképzéseikben, olyan munkaerőt képeznek, akik képesek hozzájárulni a környezet hosszú távú megőrzéséhez. Ezért egyrészt célszerű jobban meghonosítani a zöld gazdaság és a zöld készségek kifejezéseket, és azok helyes használatát (nemcsak a szakmai tudást, gyakorlatot és a környezettudatosságot, hanem többféle puha készséget), továbbá a politikai döntéshozóknak meg kell tenniük a szükséges intézkedéseket, hogy összehangolt módon lehessen végrehajtani a fenntartható fejlődés érdekében folytatott képzést mind a szaktudás, mind a képességek fejlesztése szempontjából. Több kutatásra, ismeretterjesztő segédanyagra, továbbképzésre lenne szükség, hogy a zöld készségek elterjedése több támogatáshoz jusson az egyetemi alapszakokon is.

A kutatás folytatásaként célunk egy olyan módszer kidolgozása, amely az azonosított nemzetközi és hazai jó gyakorlatokra épülve a klímainnovációhoz kapcsolódó tudásmegosztás hatékonyságának javítását célozza meg. Terveink szerint a kidolgozott módszer általánosítható lesz, így egész Közép-Európában elősegítheti a zöld készségek fejlesztését.

\section{Köszönetnyilvánítás}

Jelen kutatás a Wacław Felczak Alapítvány támogatásával, a Jagelló című pályázat keretében valósult meg. A tanulmány az Innovációs és Technológiai Minisztérium UNNP-21-5 
kódszámú Új Nemzeti Kiválósági Programjának a Nemzeti Kutatási, Fejlesztési és Innovációs Alapból finanszírozott szakmai támogatásával készült.

\section{IRODALOM}

Bailey, I. \& Caprotti, F. (2014) The Green Economy: Functional Domains and Theoretical Directions of Enquiry. Environment and Planning A: Economy and Space, Vol. 46. No. 8. pp. 1797-1813. DOI: 10.1068/a130102p

Bloom, B. S., Engelhart, M. D., Furst, E. J., Hill, W. H. \& Krathwohl, D. R. (1956) Taxonomy of Educational Objectives, Handbook I: The Cognitive Domain. New York, David McKay Co., Inc.

CEDEFOP (2011) Annual Report 2010. Luxembourg, Publications Office of the European Union. DOI: 10.2801/84544 [Letöltve: 2021. 05. 29.]

CEDEFOP (2012) A Strategy for Green Skills? A Study on Skill Need aand Training Has Wider Lessons for Successful Transition to a Green Economy. Briefing Note, February, European Centre for the Development of Vocational Training. DOI: 10.2801/16037 [Letöltve: 2021. 05. 29.]

Cynk, K. (2017) The State of the Environmental Awareness of Students from Poland, Slovakia and Ukraine - Selected Results. Civil and Environmental Engineering Reports, Vol. 24. No. 1. pp. 21-37.

European Commission (2020) European Skills Agenda for Sustainable Competitiveness, Social Fairness And Resilience. Commuunication. https://ec.europa.eu/social/main. jsp?catId=1223\&langId=en [Letöltve: 2021. 05. 29.]

ILO (2011) Skills And Occupational Needs in Renewable Energy. International Labour Office, Geneva ILO Skills and Employability Department. https://www.ilo.org/wcmsp5/ groups/public/---ed_emp/---ifp_skills/documents/publication/wcms_166823.pdf [Letöltve: 2021. 05. 29.]

Lee, T. \& van der Heijden, J. (2019) Does the Knowledge Economy Advance the Green Economy? An Evaluation of Green Jobs in the 100 Largest Metropolitan Regions in the United States. Energy E Environment, Vol. 30. No. 1. pp. 141-155. DOI: $10.1177 / 0958305 X 18787300$

Nurdiansya, N., Mulyanti, B. \& Sucita, T. (2019) Green Skills for Electrical Engineering Students. Journal of Physics: Conference Series, Vol. 1375, 012086

Pavlova, M. (2012) Generic Green Skills: Can They Be Addressed trough Technology Education? Griffith University. https://core.ac.uk/download/pdf/143873787.pdf [Letöltve: 2021. 05. 29.]

Sern, L.C., Zaime, A. F. \& Foong, L. M. (2017) Green Skills for Green Industry: A Review of Literature. Journal of Physics: Conference Series, Vol. 1019. 012030.

Szalmáné Csete M., Buzási A., Barna O. (2020) Climate Innovation and Entrepreneurship in Primary and Secondary Education in Hungary. In: Gyula ZILAHY (ed.) Sustainability in Transforming Societies. Budapest, Budapesti Műszaki és Gazdaságtudományi Egyetem, Gazdaság- és Társadalomtudományi Kar. pp. 337-350.

UN (2011) The Green Economy: Trade and Sustainable Development Implications. Background note prepared by the UNCTAD secretariat for the Ad Hoc Expert Meeting. United Nations, New York and Geneva. https:/unctad.org/system/files/official-document/ ditcted2011d5_en.pdf [Letöltve: 2021. 05.30.]

UN (2021) Green Economy, Sustainable Development Goals Knowledge Platform. https:// sustainabledevelopment.un.org/index.php?menu=1446 [Letöltve: 2021.05 .29 .] 
WRI (2011) What is a "Green Economy"? World Resource Institute. https://www.wri.org/ blog/2011/04/qa-what-green-economy [Letöltve: 2021. 01. 29.]

Zsóka Á., Marjainé Sz. Zs. \& Széchy A. (2011) A környezeti nevelés szerepe a fenntartható fogyasztás és életmód kialakításában. In: Csutora M. \& Hofmeister Tóth Á. (eds) Fenntartható fogyasztás? A fenntartható fogyasztás gazdasági kérdései. Budapest, Budapesti Corvinus Egyetem. pp. 90-109.

A cikk a Creative Commons Attribution 4.0 International License (https://creativecommons.org/licenses/ by/4.0/) feltételei szerint publikált Open Access közlemény, melynek szellemében a cikk bármilyen médiumban szabadon felhasználható, megosztható és újraközölhető, feltéve, hogy az eredeti szerző és a közlés helye, illetve a CC License linkje és az esetlegesen végrehajtott módosítások feltüntetésre kerülnek. (SID_1) 